\title{
Impact of conservatory as a passive solar design of UK dwellings
}

Joseph Amoako-Attah BSc, MBA, MSC

Doctoral Candidate and Lecturer, School of Computing and Technology, Department of Civil and Built Environment, University of West London, Ealing, London, UK
2 Ali B-Jahromi BEng, MSc, PhD, CEng, MICE

Associate Professor in Civil Engineering and Course Leader, School of Computing and Technology, Department of Civil and Built Environment, University of West London, Ealing, London, UK
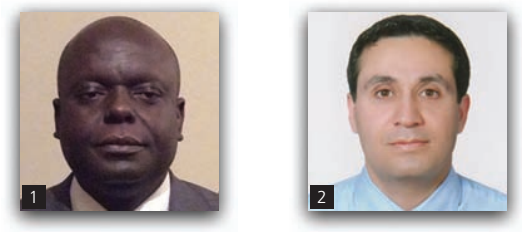

The prime goal of professionals in the built environment is to build cost-effective, environmentally sustainable buildings. This work focuses on the viability of passive solar design strategies of conservatories in the UK in mitigating the impact of future climate change. It further shows that passive solar energy utilisation in building design can contribute to the reduction of dwelling energy consumption and enhancement of indoor thermal comfort. Synergetic passive design strategies that optimise solar energy gains through thermal simulation analyses of varying future climatic conditions, occupant behaviour, building orientation, thermal mass, advance glazing, appropriate ventilation and shading, which influence the potential thermal performance of the conservatory, are devised. The balanced energy benefits of reduction in energy consumption through the application of passive solar design principles for space heating in winter and the challenge of reducing excessive solar gains in summer are analysed using the Cibse TM52 adaptive thermal comfort criteria. The results show that judicious integration of passive solar design strategies in conservatories, with increasing conservatory size in elongated south-facing orientation with an aspect ratio of at least 1.67, could decrease energy consumption, enhance thermal comfort and help to mitigate the impact of climate change when the conservatory is neither heated nor air conditioned.

\section{Notation}

$T_{\text {comf }}$ comfort temperature

$T_{\max }$ limiting maximum acceptable temperature

$T_{\min } \quad$ limiting minimum acceptable temperature

$T_{\text {od-1 }}$ daily mean outdoor temperature of the day before

$T_{\mathrm{op}} \quad$ operative temperature

$T_{\mathrm{rm}} \quad$ exponentially weighted running mean of the daily mean outdoor air temperature

$T_{\text {upp }} \quad$ absolute maximum temperature

$\alpha \quad$ constant

\section{Introduction}

The current global quest for the reduction of carbon dioxide emissions and energy consumption in buildings is driving professionals in the built environment toward passive design technologies, because these are among the most economically efficient strategies to reduce energy consumption in dwellings (Kruzner et al., 2013; Pulselli et al., 2009). This would further provide cost-effective means of daylight utilisation in buildings
(Zain-Ahmed et al., 2002). Passive solar energy utilisation in buildings has been a relevant design feature dating back thousands of years. The archaeological findings of the architectural buildings of Anastasi Indians, Egyptians, Greeks and Romans point to the use of passive solar ideas in buildings during these periods of civilisation (Burns and Kabak, 2014). The harnessing of the abundance and importance of passive solar energy in building cannot be over emphasised. About $0.01 \%$ of the total amount of solar energy reaching the planet is estimated to be sufficient to meet all mankind's energy needs (BRE, 1988). The Department of Energy of the UK indicates that the amount of solar energy received by a typical dwelling in the UK in a year is more than enough compared to the total household energy consumption (BRE, 1988). Research further indicates that incorporating passive solar energy design principles has the potential to contribute to about a third of the total heating needs in the buildings in the UK (BRE, 1988). Thus although the UK is not endowed with solar energy all year round, appropriate application of efficient passive solar design principles could 
contribute significantly to the reduction of carbon dioxide emissions for current and future climate change mitigation and offer the economic benefits of reducing building thermal energy demand (Oliveira Panao et al., 2012). However, studies also indicate that lack of comprehensive and effective passive solar design strategies in buildings would lead to increase in household energy demand (Taleb, 2014).

\subsection{Concept of passive solar design}

Passive solar building design entails the harnessing of solar energy to facilitate winter heating and its pragmatic exclusion during summer to offset indoor overheating temperatures in order to provide comfort, reduce energy demand and carbon dioxide emission. A comprehensive passive solar design seeks not only to optimise the use of solar energy for heating, but also to provide adequate daylighting and natural ventilation without reliance on power-driven mechanical systems. During the non-heating period of the year adequate levels of shading and ventilation are provided to reduce the amount of solar energy admitted into the building. The basis of passive solar heating is to harness the solar energy through a glazing element, through which radiant energy is received into a building, and partly to use it to heat the building; the remainder being stored in a thermal mass as thermal energy for subsequent release to the building in the absence of the sun (Anderson and Michal, 1978; Mihalakakou and Ferrante, 2000). Kochaniuk (2012) outlined the three primary solar configurations of energy transfer mechanisms as the direct gain, indirect gain and isolated gain. This work focuses on the conservatory as a form of isolated gain passive solar system.

\subsection{Principles of the conservatory as a passive solar design}

A conservatory is an isolated gain passive solar system and mostly glazed enclosed space attached to one or more facades of a dwelling; it serves as a thermal buffer to affect thermal and ventilation losses and also facilitates pre-heated ventilation to the main dwelling. Currently, legislation has been the main driver for efficient conservatory design in buildings (Clarke et al., 2008). The UK building regulation 2010 Part LIB (CLG, 2010a) mandates that a conservatory will generally be exempted from the regulation if it is built at the ground level and has a floor area of less than $30 \mathrm{~m}^{2}$, and the conservatory depends on the dwelling's heating system (Planning Portal, 2014). With conservatories of area more than $30 \mathrm{~m}^{2}$, there must be effective thermal separation between the conservatory and the main dwelling, and the conservatory should be glazed according to the standards set out in the building regulation (Planning Portal, 2014). The window industry regulator of England and Wales, Fenestration Selfassessment Scheme (FENSA) also stipulates that a conservatory must be physically separated from the main dwelling by an external door and/or windows and should not have less than $75 \%$ of its roof area and $50 \%$ of its wall area made from translucent material (FENSA, 2014). The standard assessment procedure (BRE, 2012) also directs that the U-values for conservatory building fabric, windows and doors must be similar to, or not more than, that of the 'corresponding exposed elements elsewhere in the dwelling' (BRE, 2014).

Synergetic conservatory design strategies that take into account the inter-relationship of the design variables can optimise the energy balance of the dwelling, resulting in energy consumption and carbon dioxide emission reductions and thermal comfort (Bakos and Tsagas, 2000; BRE, 1988). The three-fold energy balance optimisation can be achieved through the design of the conservatory as an efficient solar gain system, with buffer or insulation effect and to control pre-heat ventilation of air passing through it to the dwelling (Mihalakakou and Ferrante, 2000). Boyle indicated in his publication that thermal buffering of a south side conservatory, preheating ventilation air from the conservatory to the dwelling and solar gains contribute $15 \%, 55 \%$ and $30 \%$, respectively, of energy gains (Boyle, 2012). Bataineh and Fayez (2011), using a numerical model to analyse the thermal performance of a building attached sunspace, indicated that a $42 \%$ reduction in annual heating and cooling load could be achieved. Research work indicates that the success of an efficient solar gain system depends on the complex dynamic function (Morrissey et al., 2011) of varying future climatic conditions and local topography (Lau et al., 2007), variable occupant behaviour, building orientation (Morrissey et al., 2011), adequate provision of thermal mass, advance facade glazing design, appropriate ventilation and sufficient level of shading (Aksoy and Inalli, 2006; Ralegaonkar and Gupta, 2010; Yohanis and Norton, 2002). Failure to give holistic consideration to the design strategies may affect the efficient thermal performance of the whole dwelling.

\subsection{Cibse weather files}

In building performance practice, it is imperative to secure reliable formatted multi-year weather files, which have been prepared from reliable meteorological predictions. In 2008, Chartered Institution of Building Services Engineers (Cibse) released two sets of future weather files, the test reference years (TRYs) and the design summer years (DSYs) based on the UKCIP02 climate projections (Hulme et al., 2002). The methodology used to produce the Cibse future weather files was the 'morphing' methodology, which adjusted the historic weather files to the climate projection (Cibse TM48, Cibse, 2009; Mylona, 2012). This data set is deterministic in nature (Tian and de Wilde, 2011).

The TRYs weather files based on average years computations are earmarked for average energy demand in building calculations. The DSYs weather files, which are related to a year with an extreme, hot summer, defined as the 'third hottest summer in a 20-year baseline' (ranked based on the highest measured dry bulb temperature in the period April-September), are earmarked for overheating analysis (Cibse TM55, Cibse, 2014). The UKCIP02 data generation is based on four of the six marker projected emission scenarios of the IPCC special report on emission scenarios (SRES), A1F1, A2, B2 and B1; namely, high, medium-high, medium-low and low, respectively, which underpinned the UK's Meteorological Office Hadley Centre (MOHC) climate change model (HadCM3) and future global 
climate model (Cibse TM48, Cibse, 2009). The four projected emission scenarios range from future low-energy carbon dioxide emission to a high fossil fuel usage.

Although a high level of confidence has been expressed in the weather data set based on UKCIP02 in predicting annual average temperature change over varied geographical locations (Cibse TM48, Cibse, 2009), the Cibse TM48 outlines uncertainties surrounding the need for better climatic projection weather data for building simulation analysis. Among the low-level confidence issues raised are the projected changes in the cloud cover and larger projected changes in summer temperatures when compared to winter temperatures (Cibse TM48, Cibse, 2009).

In 2009 the UK's Department of the Environment, Food and Rural Affairs (Defra) published the UK climate projections UKCP09 (Murphy et al., 2009). These climatic projections supersede the UKCIP02 weather projections (UK Climate Projections, 2010). The UKCP09 probabilistic weather predictions are modernistic climate projections based on cutting-edge methodology, which uses probabilities for different levels of future climate change to model accurately the future climate patterns (Jenkins et al., 2009; Tian and de Wilde, 2011).

The Cibse weather data set, which is underpinned by the UKCIP02 climate change scenarios, was used in the present study owing to the unfortunate lack of availability of the Cibse weather data set based on UKCP09 at the time of the study.

\section{Methodology}

\subsection{Background}

The goal is to verify through a series of simulations the optimisation of energy consumption and thermal comfort performance of habitable conservatories. The work employs integrated passive design strategies of varying future climatic conditions, variable occupant behaviour, building orientation, adequate provision of thermal mass, advanced glazing, appropriate ventilation and sufficient level of external shading. Moreover, the study makes use of the UK Cibse TRY and DSY of current and future weather data, which incorporate the UKCIP02 projections and the newly developed Cibse criteria (Cibse TM52, Cibse, 2013) as an assessment tool.

Thermal analysis simulation software TAS version 9.3.1, a building simulation program developed by Engineering Development Solutions Software (EDSL, 2014), is used as a dynamic simulation modeller to model and simulate the thermal performance. This current version has been approved and has the full accreditation for the UK building regulations 2013; it has also demonstrated compliance to various BS EN ISO standards (EDSL, 2014). TAS has the capability to overcome the challenge of applying the 'vast quantity of data to assess the probabilistic performance of buildings in the future' (Williams et al., 2011). Moreover, it offers complete solution as a powerful modelling and simulation tool, and realistically accounts for occupied summer hours based on the Cibse TM52 adaptive overheating criteria. The TAS modeller has the capability of identifying and fixing gaps in the space boundaries, incorrectly orientated surfaces and adjacency problems. Moreover, TAS has the facility to optimise the building environment, energy performance and occupant comfort. It also offers ray tracing and radiosity results; the TAS daylight method can also produce useful daylight illuminance (UDI), daylight autonomy (DA) and daylight distribution (EDSL, 2014).

\subsection{Thermal analysis simulation three-dimensional (3D) modelling and simulation}

The detached dwelling used as the case study is 49 Carnation Drive; a 1995 three-bedroom house located in Bracknell, Berkshire, with the latitude, longitude and time zone of $51.42^{\circ}$ north, $-0.75^{\circ}$ east and UTC $+0 \cdot 0$, respectively. Bracknell, Berkshire is about $48 \mathrm{~km}$ from central London, the closest weather station. Hence the current Cibse London TRY and DSY are, respectively, chosen for the heating season and non-heating season analysis. The thermo-physical properties of the conservatory design were selected using an heuristic approach based on knowledge of the building regulations, educated guesswork, rule of thumb and experience in the use of design standards. The outputs used in the analysis are the indoor operative temperatures for thermal comfort analysis, total annual energy consumption, annual natural gas consumption and building emission rate for both the main dwelling and the conservatory.

The floor area of the main building is $115 \cdot 3 \mathrm{~m}^{2}$ with a total surface area of $17 \cdot 16 \mathrm{~m}^{2}$ of glazing. Three typical dwarf wall conservatory designs were built at the ground floor with varying internal floor area between $4 \mathrm{~m}^{2}$ and $30 \mathrm{~m}^{2}$ to determine the optimum design for efficient thermal performance. The conservatory design is thus within the limits specified by the UK building regulations, which mandate a conservatory with a floor area not exceeding $30 \mathrm{~m}^{2}$ can be exempted from planning application. The maximum height for all design considerations is $4 \mathrm{~m}$. The height of the dwarf wall is $525 \mathrm{~mm}$. Thermal mass specification for the conservatory dwarf wall and floor is equivalent to the Passivhaus standard (Passivhaus Homes, 2013). The chosen dwarf wall design for the conservatory with its vertical thermal mass surfaces will facilitate the absorption of excess solar radiation during non-heating periods and thus reduce temperature swings. Low-emissivity argon-filled double glazing is selected for all design considerations, based on findings outlined in previous studies, because it offers the most efficient thermal performance and economic benefits. The roof and the wall of the conservatory consisted of at least $75 \%$ and $50 \%$ of glazing material, respectively. The selected material for the frame was polyvinyl chloride (PVC). The conservatory fenestration dimensions were selected to meet the design criteria specified in the British Standard BS 5952:1991 (BSI, 1991) and Part F of the UK building regulations (CLG, 2010b). The conservatory is separated from the main dwelling by operable doors and windows and, in heating scenario 3 (as shown in Table 1), the conservatory was heated, but never air conditioned in all scenarios. 
Modelling assumptions and parameters

\begin{tabular}{|c|c|c|c|c|c|}
\hline & & \multicolumn{2}{|c|}{ Non-heating season } & \multicolumn{2}{|c|}{ Heating season } \\
\hline & & Day & Night & Day & Night \\
\hline Day lighting & & $\begin{array}{l}\text { Clear sky } \\
\text { Accuracy - reflective } \\
\text { convergence for details } \\
\text { analysis }\end{array}$ & N/A & $\begin{array}{l}\text { Overcast sky } \\
\text { Accuracy - reflective } \\
\text { convergence for details } \\
\text { analysis }\end{array}$ & N/A \\
\hline $\begin{array}{l}\text { Weather } \\
\text { data }\end{array}$ & & DSY & DSY & TRY & TRY \\
\hline \multirow[t]{3}{*}{ Ventilation } & Scenario 1 & $\begin{array}{l}\text { Adequate cross-ventilation } \\
\text { in all directions. } \\
\text { Openable window } \\
\text { proportion } 100 \% \text {; at least } \\
5 \% \text { of total floor area. } \\
\text { Set openable window } \\
\text { temperature } 20-21^{\circ} \mathrm{C} \text {. } \\
\text { Openable window } \\
\text { schedule } 4 \text { a.m. to } 8 \text { p.m. }\end{array}$ & $\mathrm{N} / \mathrm{A}$ & $\begin{array}{l}\text { Optimum cross-ventilation } \\
\text { between conservatory } \\
\text { south-facing fenestration } \\
\text { and main building north } \\
\text { fenestration. } \\
\text { Openable conservatory } \\
\text { lower/bottom window } \\
\text { proportion } 25 \% \text {. } \\
\text { Openable main building } \\
\text { north-facing window } \\
\text { proportion } 5 \% \text {. } \\
\text { Set conservatory openable } \\
\text { window temperature } \\
10-11^{\circ} \mathrm{C} \text {, main building } \\
20-21^{\circ} \mathrm{C} \text {. } \\
\text { Openable window } \\
\text { schedule } 10 \text { a.m. to } \\
3 \text { p.m. }\end{array}$ & $\begin{array}{l}\text { Doors/windows } \\
\text { between conservatory } \\
\text { and main building } \\
\text { closed. Conservatory } \\
\text { serves as buffer }\end{array}$ \\
\hline & Scenario 2 & $\begin{array}{l}\text { Adequate cross-ventilation } \\
\text { in all directions. } \\
\text { Openable window } \\
\text { proportion } 100 \% \text {; at least } \\
5 \% \text { of total floor area. } \\
\text { Set openable window } \\
\text { temperature } 20-21^{\circ} \mathrm{C} \text {. } \\
\text { Openable window } \\
\text { schedule } 24 \mathrm{~h}\end{array}$ & $\begin{array}{l}\text { Adequate cross-ventilation } \\
\text { in all directions. } \\
\text { Openable window } \\
\text { proportion } 100 \% \text {; at least } \\
5 \% \text { of total floor area. } \\
\text { Set openable window } \\
\text { temperature } 20-21^{\circ} \mathrm{C} \text {. } \\
\text { Openable window } \\
\text { schedule } 24 \mathrm{~h}\end{array}$ & $\begin{array}{l}\text { Optimum cross-ventilation } \\
\text { between conservatory } \\
\text { south-facing fenestration } \\
\text { and main building north } \\
\text { fenestration. } \\
\text { Openable conservatory } \\
\text { lower/bottom window } \\
\text { proportion } 25 \% \text {. } \\
\text { Openable main building } \\
\text { north-facing window } \\
\text { proportion } 5 \% \\
\text { Set conservatory openable } \\
\text { window temperature } \\
10-11^{\circ} \mathrm{C} \text {, main building } \\
20-21^{\circ} \mathrm{C} \\
\text { Openable window } \\
\text { schedule } 10 \text { a.m. to } \\
3 \text { p.m. }\end{array}$ & $\begin{array}{l}\text { Doors/windows } \\
\text { between conservatory } \\
\text { and main building } \\
\text { closed. Conservatory } \\
\text { serves as buffer }\end{array}$ \\
\hline & Scenario 3 & $\begin{array}{l}\text { Adequate cross-ventilation } \\
\text { in all directions. } \\
\text { Openable window }\end{array}$ & $\begin{array}{l}\text { Adequate cross-ventilation } \\
\text { in all directions. } \\
\text { Openable window }\end{array}$ & $\begin{array}{l}\text { Optimum cross-ventilation } \\
\text { between conservatory } \\
\text { south-facing fenestration }\end{array}$ & $\begin{array}{l}\text { Doors/windows } \\
\text { between conservatory } \\
\text { and main building }\end{array}$ \\
\hline
\end{tabular}

Table 1. Modelling and simulation parameters and assumptions.

HVAC: heating, ventilation and air conditioning (continued on next page) 
Modelling assumptions and parameters

\begin{tabular}{cccc}
\hline & Non-heating season & & Heating season \\
Day & Night & Day & Night
\end{tabular}

proportion 100\%; at least $5 \%$ of total floor area. Set openable window temperature $20-21^{\circ} \mathrm{C}$. Openable window schedule $24 \mathrm{~h}$

Shading Scenario 1 No shading

Scenario 2 Roof (overhang/awnings) and south-facing conservatory side shading. South shading schedule 10 a.m. to 3 p.m.

Scenario 3 Roof (overhang/awnings) and south-, east- and west-facing conservatory side shading.

East shading schedule 4 a.m. to 11 a.m. West shading schedule 12 noon to 8 p.m.

Heating Scenario 1 N/A proportion 100\%; at least $5 \%$ of total floor area. Set openable window temperature $20-21^{\circ} \mathrm{C}$. Openable window schedule $24 \mathrm{~h}$
N/A

N/A

N/A and main building north fenestration.

Openable conservatory lower/bottom window proportion $25 \%$. Openable main building north-facing window proportion 5\% Set conservatory openable window temperature $20-21^{\circ} \mathrm{C}$, main building $20-21^{\circ} \mathrm{C}$

Openable window schedule 10 a.m. to 3 p.m.

N/A

N/A

N/A

Main building:

Fuel source is natural gas

HVAC type - central heating using water radiators

Design flow rate $-200 \mathrm{l} / \mathrm{s}$ SFP, $0.4 \mathrm{~W} / \mathrm{l} / \mathrm{s}$

Distribution efficiency 90\%

Boiler efficiency $91 \%$

Conservatory:

No heating applied
Main building:

closed. Conservatory serves as buffer

Internal shading device coupled with coated low-e double glazed Internal shading device coupled with coated low-e double glazed

Internal shading device coupled with coated low-e double glazed

Fuel source is natural gas

HVAC type - central heating using water radiators Design flow rate $200 \mathrm{l} / \mathrm{s}$, SFP, $0.4 \mathrm{~W} / \mathrm{l} / \mathrm{s}$ Distribution efficiency 90\%

Boiler efficiency 91\% Conservatory: No heating applied

Table 1. Continued 
Modelling assumptions and parameters

\begin{tabular}{|c|c|c|c|c|}
\hline & \multicolumn{2}{|c|}{ Non-heating season } & \multicolumn{2}{|c|}{ Heating season } \\
\hline & Day & Night & Day & Night \\
\hline Scenario 2 & $\mathrm{~N} / \mathrm{A}$ & N/A & $\begin{array}{l}\text { Main building: } \\
\text { Fuel source is natural gas } \\
\text { HVAC type - central } \\
\text { heating using water } \\
\text { radiators } \\
\text { Design flow rate - } 200 \mathrm{l} / \mathrm{s} \text {, } \\
\text { SFP, } 0 \cdot 4 \mathrm{~W} / \mathrm{l} / \mathrm{s} \\
\text { Distribution efficiency } \\
90 \% \\
\text { Boiler efficiency } 91 \% \\
\text { Conservatory: } \\
\text { No heating applied }\end{array}$ & $\begin{array}{l}\text { Main building: } \\
\text { Fuel source is natural } \\
\text { gas } \\
\text { HVAC type - central } \\
\text { heating using water } \\
\text { radiators } \\
\text { Design flow rate - } \\
200 \mathrm{l} / \mathrm{s}, \mathrm{SFP}, 0 \cdot 4 \mathrm{~W} / \mathrm{l} / \mathrm{s} \\
\text { Distribution efficiency } \\
90 \% \\
\text { Boiler efficiency } 91 \% \\
\text { Conservatory: } \\
\text { No heating applied }\end{array}$ \\
\hline Scenario 3 & N/A & N/A & $\begin{array}{l}\text { Main building: } \\
\text { Fuel source is natural gas } \\
\text { HVAC type - central } \\
\text { heating using water } \\
\text { radiators } \\
\text { Design flow rate - } 200 \mathrm{l} / \mathrm{s} \text {, } \\
\text { SFP, } 0 \cdot 4 \mathrm{~W} / \mathrm{l} / \mathrm{s} \\
\text { Distribution efficiency } \\
90 \% \\
\text { Boiler efficiency } 91 \% \\
\text { Conservatory: } \\
\text { Heating applied as main } \\
\text { building }\end{array}$ & $\begin{array}{l}\text { Main building: } \\
\text { Fuel source is natural } \\
\text { gas } \\
\text { HVAC type - central } \\
\text { heating using water } \\
\text { radiators } \\
\text { Design flow rate - } \\
200 \mathrm{l} / \mathrm{s}, \text { SFP, } 0.4 \mathrm{~W} / 1 / \mathrm{s} \\
\text { Distribution efficiency } \\
90 \% \\
\text { Boiler efficiency } 91 \% \\
\text { Conservatory: } \\
\text { Heating applied as } \\
\text { main building }\end{array}$ \\
\hline
\end{tabular}

Table 1. Continued

Table 1 presents the summary of the varying scenarios with their distinct ventilation and shading mitigation strategies. For instance, scenario 2 has the same ventilation strategy as scenario 3 , but a different shading strategy. In this scenario the investigation focuses on the shading strategy but not the ventilation strategy. A similar idea is seen in other scenarios.

The choice of the $10-11^{\circ} \mathrm{C}$ temperature for the scenarios where the conservatory lower windows open in the heating season is underpinned by the use of the conservatory for pre-heating ventilation air. This is done to reduce the dwelling heating load. Generally, for a conservation to function as a solar collector, the temperature of the conservatory must be higher than the main dwelling (BRE, 1988). However, conservatories used for preheating ventilation air can change the energy balance of a house. Pre-heating ventilation air is a phenomenon where heat gain from the main dwelling by the conservatory raises the conservatory's air temperature above the ambient temperature and, on the basis of controlled ventilation, the incoming external air is heated up before it is heated by the dwelling auxiliary heating system to the desired temperature for the attainment of thermal comfort (BRE, 1988). This process facilitates the reduction of auxiliary heating demand of the dwelling. According to BRE (1988), 'there will be no threshold above which the conservatory temperature has to rise before solar gain can be used. Any increase in temperature represents a useful heat gain'. However, BRE (1988) indicates that, with a scenario of $4^{\circ} \mathrm{C}$ external temperature and about $9^{\circ} \mathrm{C}$ day-time air temperature, there is a potential to reduce the dwelling auxiliary heating load by a third. The study thus sets the conservatories' openable windows temperature for pre-heating to be $10-11^{\circ} \mathrm{C}$.

The basis of the various scenarios in Table 1 is to optimise solar radiation gain and adequate ventilation in the dwelling throughout the seasons. Moreover, this work uses awnings incorporated with overhang design as external shading to control the admission of solar radiation gains. In addition, low-emissivity argon-filled double glazing is used for all glazed areas with an overall width of $4+16+4 \mathrm{~mm}$ and solar heat gain coefficient 

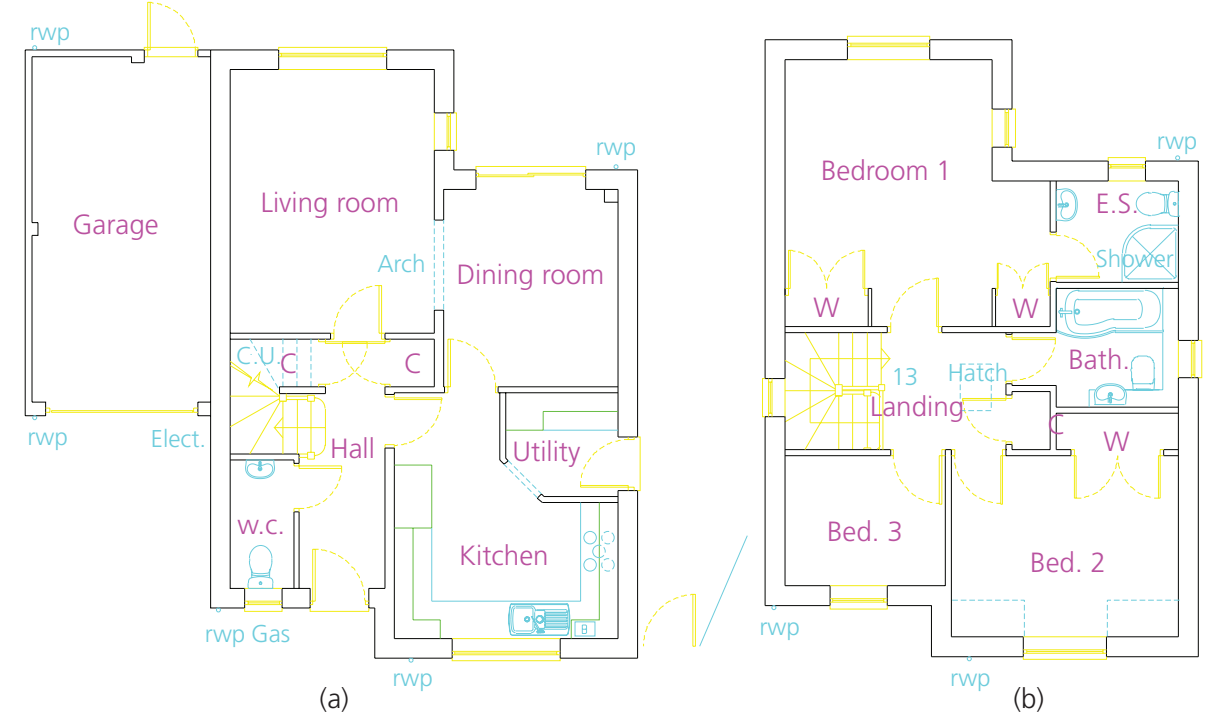

(b)

Figure 1. (a) Ground floor plan; (b) first floor plan (scale 1:50)

(SHGC or g-value) of $0 \cdot 578$. The low-emissivity argon-filled double glazing contributes to the maximisation of solar gains in the heating season and its mid glass panes also offer a shading effect to mitigate overheating. Furthermore, a vertical conservatory glazing design was selected instead of sloped glazing, to minimise overheating.

The data used are the AutoCAD two-storey residential detached buildings architectural drawings of 49 Carnation Drive (Figures 1(a) and 1(b)). The building drawings consisted of the ground floor and first floor plans. Detailed modelling and simulation processes using TAS software by EDSL and the modelling assumption have been clearly outlined in previous publications by the present authors (Amoako-Attah and B-Jahromi, 2014, 2015). Figure 2 outlines the methodology used in the modelling and simulation processes. The steps include the Cibse Guide A (Cibse, 2006) internal conditions specifications used in the simulation process and the UK building regulations studio simulation process.

\subsection{Adopting Cibse TM52 criteria as overheating assessment tool}

Thermal comfort (indoor operative temperature) depends on four basic environmental factors of air temperature, the mean radiant temperature, the relative air velocity and relative humidity. One of the main functions of residential buildings is to provide healthy and comfortable environments to the occupants. Buildings must therefore be designed and built by taking cognisance of the physiological reactions of the occupants due to their temperature and humidity tolerance.

The Cibse TM52 (Cibse, 2013) limits of thermal comfort focus mainly on avoiding overheating in a free-running European building during the non-heating season. The European standard BS EN 15251 (BSI, 2007), upon which the Cibse TM52 is based, provides both upper and lower limiting values for operative temperatures under various categories.

The BS EN 15251 equation for comfort temperature is given as

1. $T_{\mathrm{comf}}=0 \cdot 33 T_{\mathrm{rm}}+18 \cdot 8$

where $T_{\text {comf }}$ is the comfort temperature and $T_{\mathrm{rm}}$ is the exponentially weighted running mean of the daily mean outdoor air temperature.

The general equation of the exponentially weighted running mean temperature for any day is given as

2. $T_{\mathrm{rm}}=(1-\alpha)\left(T_{\mathrm{od}-1}+\alpha T_{\mathrm{od}-2}+\alpha^{2} T_{\mathrm{od}-3} \cdots\right)$

where $\alpha$ is a constant of less than one and $T_{\text {od-1 }}, T_{\text {od-2 }}, T_{\text {od-3 }}$, are the daily mean outdoor temperatures for yesterday, the day before and so on.

The simplified equation of the exponentially weighted running mean is given as

3. $T_{\mathrm{rm}}=(1-\alpha) T_{\mathrm{od}-1}+\alpha T_{\mathrm{rm}-1}$

In situations that lack an extensive run of days, the BS EN 12521 (BSI, 2007) specifies Equation 2 as an approximated method for computing the exponential weight running mean using the outdoor mean temperatures for the last $7 \mathrm{~d}$ with the $\alpha$ value equal to $0 \cdot 8$.

$$
\begin{aligned}
T_{\mathrm{rm}} & =\left(T_{\text {od-1 }}+0 \cdot 8 T_{\text {od-2 }}+0 \cdot 6 T_{\text {od-3 }}+0 \cdot 5 T_{\text {od-4 }}\right. \\
& \left.+\quad+0 \cdot 4 T_{\text {od- }-5}+0 \cdot 3 T_{\text {od- } 6}+0 \cdot 2 T_{\text {od- }-7}\right) / 3 \cdot 8
\end{aligned}
$$



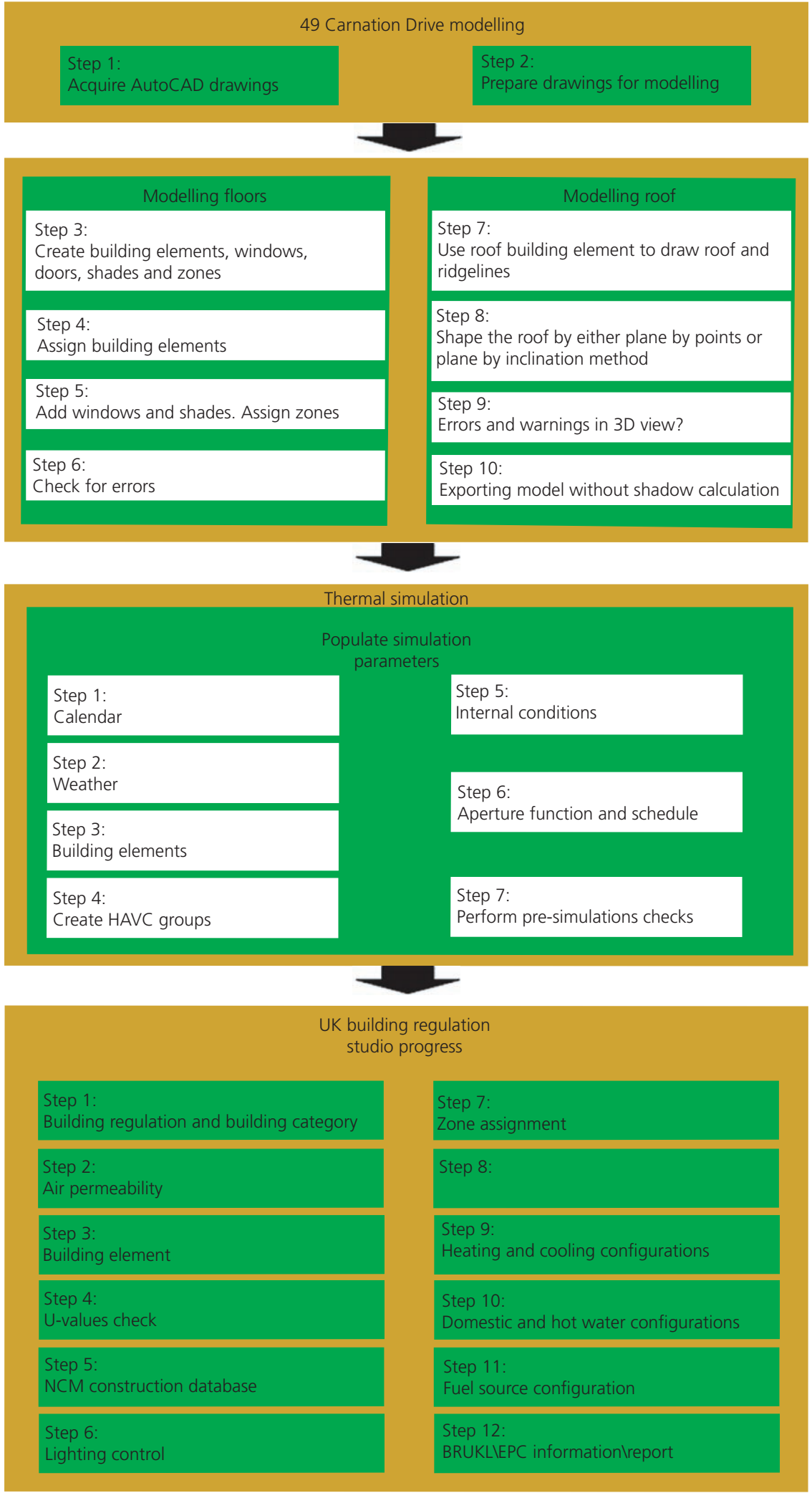

Figure 2. Methodology for modelling and simulating detached dwelling with attached conservatory thermal performance. NCM, National Calculation Method; BRUKL, Building Regulation United Kingdom Part L; EPC, Energy Performance Certificate 
The Cibse TM52 criteria focus on the category II limits in BS EN 15251 (BSI, 2007). This limit earmarks a suggested acceptable temperature of $\pm 3 \mathrm{~K}$ in relation to the comfort temperature for naturally ventilated buildings.

With a known value for the exponentially weighted running mean, $T_{\mathrm{rm}}$, the limiting maximum and minimum acceptable temperatures can therefore be calculated using Equation 5

5. $T_{\max }=0.33 T_{\mathrm{rm}}+21 \cdot 8$

All the Cibse TM52 criteria are governed by the difference between the actual operative temperature in the room $\left(T_{\mathrm{op}}\right)$ and the limiting maximum acceptable temperature, $T_{\max }$; this is given by Equation 6 as

6. $\Delta T=T_{\text {op }}-T_{\max }$

The Cibse TM52 guideline specifies three criteria for defining overheating in free running buildings: the 'hours of exceedance', 'weighted exceedance' and 'upper temperature limit' are the first, second and third criteria, respectively. A dwelling would be considered overheated if any two of the three criteria are exceeded (Cibse TM52, Cibse, 2013). The hours of exceedance criterion stipulates the duration of temperatures above thermal comfort levels and sets the limit of the number of hours during which the operative temperature can exceed the limiting maximum acceptable temperature by one degree Kelvin or more during a non-heating season of 1 May to 30 September (Cibse TM52, Cibse, 2013). This number of hours should not exceed $3 \%$ of a particular zone's occupied hours. The daily weighted exceedance criterion stipulates a daily limit of severity (a function of temperature increase and duration) above which overheating can be classified (Cibse TM52, Cibse, 2013). Cibse TM52 earmarks the limiting value of 6 for the severity of overheating for the daily weighted exceedance criterion (Cibse TM52, Cibse, 2013). The upper limit earmarks an absolute maximum temperature; a set temperature value for the difference between the indoor operative temperature and limiting maximum acceptable temperature should not be more than four degrees (Cibse TM52, Cibse, 2013).

\section{Thus}

7. $T_{\text {upp }}=T_{\max }+4$

\section{Results and discussion}

The analysis of case study building 49 Carnation Drive - a 1995, three-bedroom, two-storey, residential, detached building located in Bracknell, Berkshire - with the three conservatory designs is presented below. Figures 3(a)-3(d) represent the outcome of the modelling process. The entire major facade of the conservatories had a southern orientation with an aspect ratio of at least 1.67.

\subsection{Energy performance results and analysis}

Figures 4-6 give the statistical results of the energy performance of annual energy consumption, building emission rate and annual natural gas consumption for the current and future weather data set for all three conservatory design scenarios.

The annual energy consumption results indicated in Figure 4 show an observable decrease in energy consumption for all the three conservatory designs in scenario 2 , when the attached conservatory to the main building is unheated throughout the heating season. A declining trend is observed in the respective climate change progression timelines of current, 2020s, 2050s and 2080s for all conservatory designs. The values of mean percentage decrease of annual energy consumption for conservatories 1 to 3 was $12 \cdot 17$, $14 \cdot 23$ and $21 \cdot 45$, respectively, and these amount to $3 \cdot 98,4 \cdot 72$ and $7 \cdot 13 \mathrm{kWh} / \mathrm{m}^{2}$, respectively. This declining trend points to a general decrease in annual energy consumption with progressive increase in conservatory floor area/surface area and indicates a significant contribution to decreasing dwelling energy consumption when a conservatory is attached to it.

At periods of low air temperatures coupled with high solar radiation, pre-heated air in the conservatory is transferred to the main dwelling. This convective heat gain leads to a reduction of the main building heat load contribution from a mechanical heating system. In addition, increasing the conservatory dimension along the southern orientation contributes to the provision of additional insulation of the main dwelling. This increasing buffer effect results in a decrease in heat loss from the main dwelling and hence reducing its heating load. At the same time, the progressive increase of the elongated south facade of the conservatory with its coated, low-emissivity double glazing, coupled with the effective design of awnings/overhang which maximise the incident solar radiation collection during the heating season, low-level ventilation and the provision of adequate thermal mass for the conservatory floor and dwarf walls all contribute to the passive design consideration leading to a reduction in the heating load of the main dwelling.

However, the annual energy consumption gains are negated in scenario 3 when the conservatories are heated during the heating season. The mean percentages of annual energy consumption lost due to the heating of the three conservatories were observed to be $9 \cdot 82,16.63$ and 29.99 for the current and future weather data set. This trend points to increasing loss of overall annual energy consumption with increasing conservatory dimensions when the conservatories are heated during the heating season.

The building emission rate results indicated in Figure 5 show an observable decrease in emission rate for all the three conservatory designs in scenario 2, when the attached conservatory to the main building is unheated throughout the heating season. The declining trend is observed in the respective climate change progression timelines of current, 2020s, 2050s and 2080s for all conservatory designs. The mean percentage decreases of building emission rate 
Engineering Sustainability Volume 169 Issue ES5

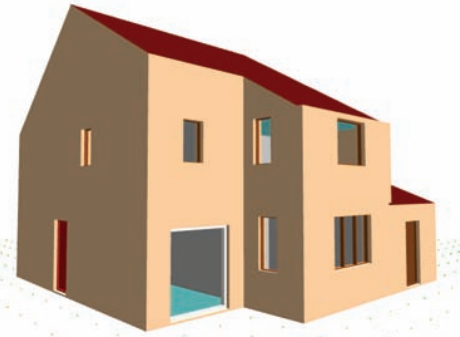

(a)

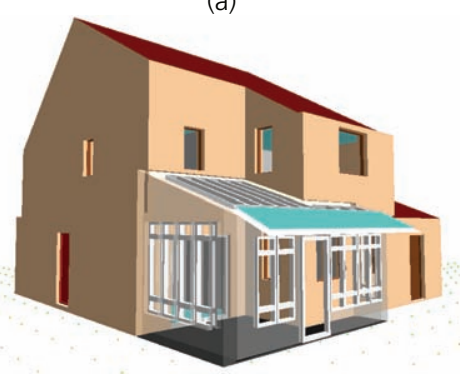

(c)

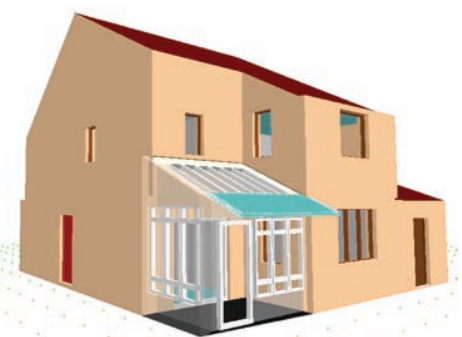

(b)

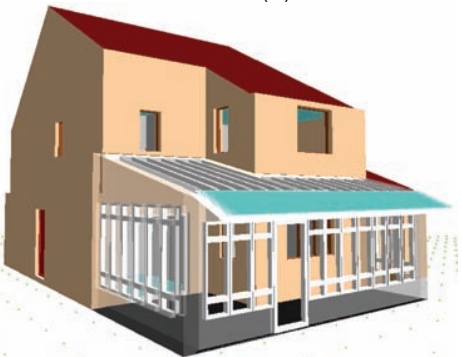

(d)

Figure 3. Modelling results for 49 Carnation Drive: (a) south

facing; (b) including conservatory 1 ; (c) including conservatory 2;

(d) including conservatory 3

for conservatories 1 to 3 were $4 \cdot 54,6 \cdot 62$ and $11 \cdot 07$, respectively, and these amount to $1.20,1.75$ and $2.93 \mathrm{kgCO}_{2} / \mathrm{m}^{2}$, respectively. This declining trend points to a general decrease in building emission rate with progressive increase in conservatory floor area/ surface area, and indicates a significant contribution to decrease in dwelling emission rate when a conservatory is attached to it. The reasons for the declining trend could also be ascribed to the reasons outlined earlier in relation to the declining trend associated with the annual energy consumptions. Nevertheless, the building emission rate gains are also negated in considering scenario 3 , when the conservatories are heated during the heating season. The mean percentages of building emission rate lost due to the heating of the three conservatories were observed to be $2 \cdot 38$, $4 \cdot 25$ and $7 \cdot 22$ for the current and future weather data sets.

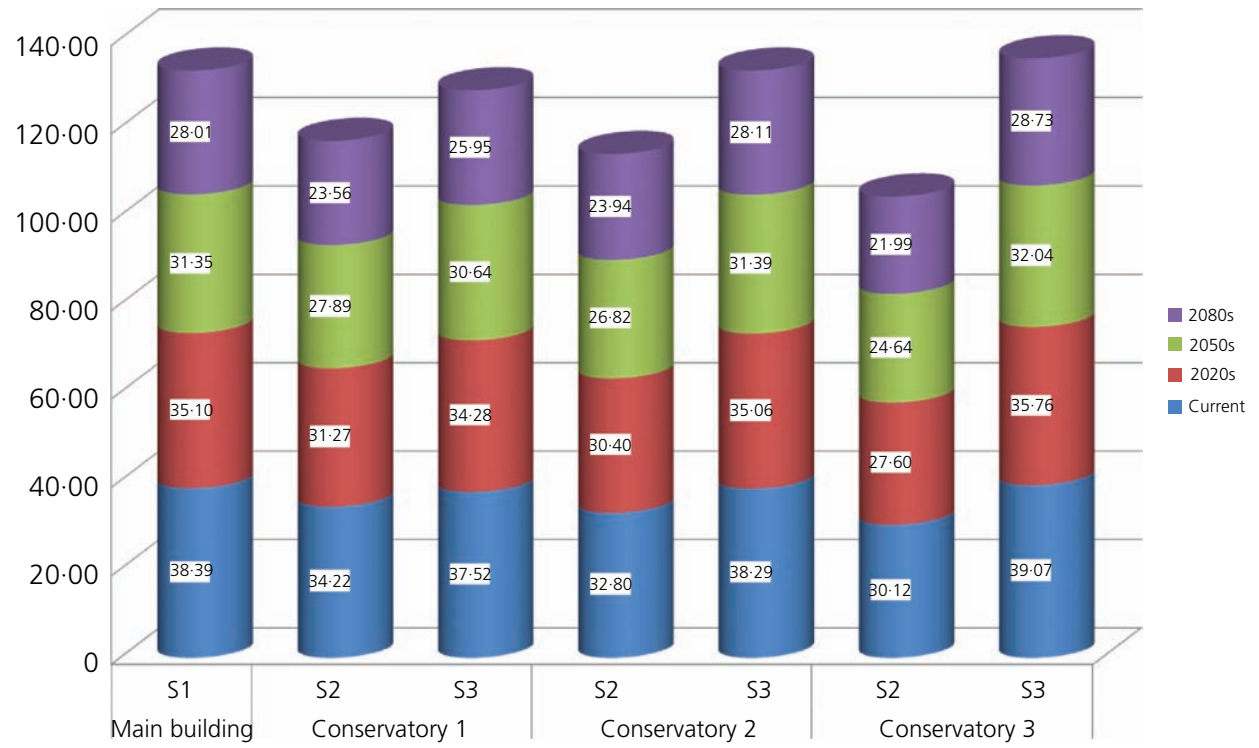

S1 - Scenario 1 - Main building heating in the absence of conservatory

S2 - Scenario 2 - Main building heating with conservatory attached but conservatory is not heated

S3 - Scenario 3 - Main building heating with conservatory attached and conservatory is heated

Figure 4. Annual energy consumption $\left(\mathrm{kWh} / \mathrm{m}^{2}\right)$ 


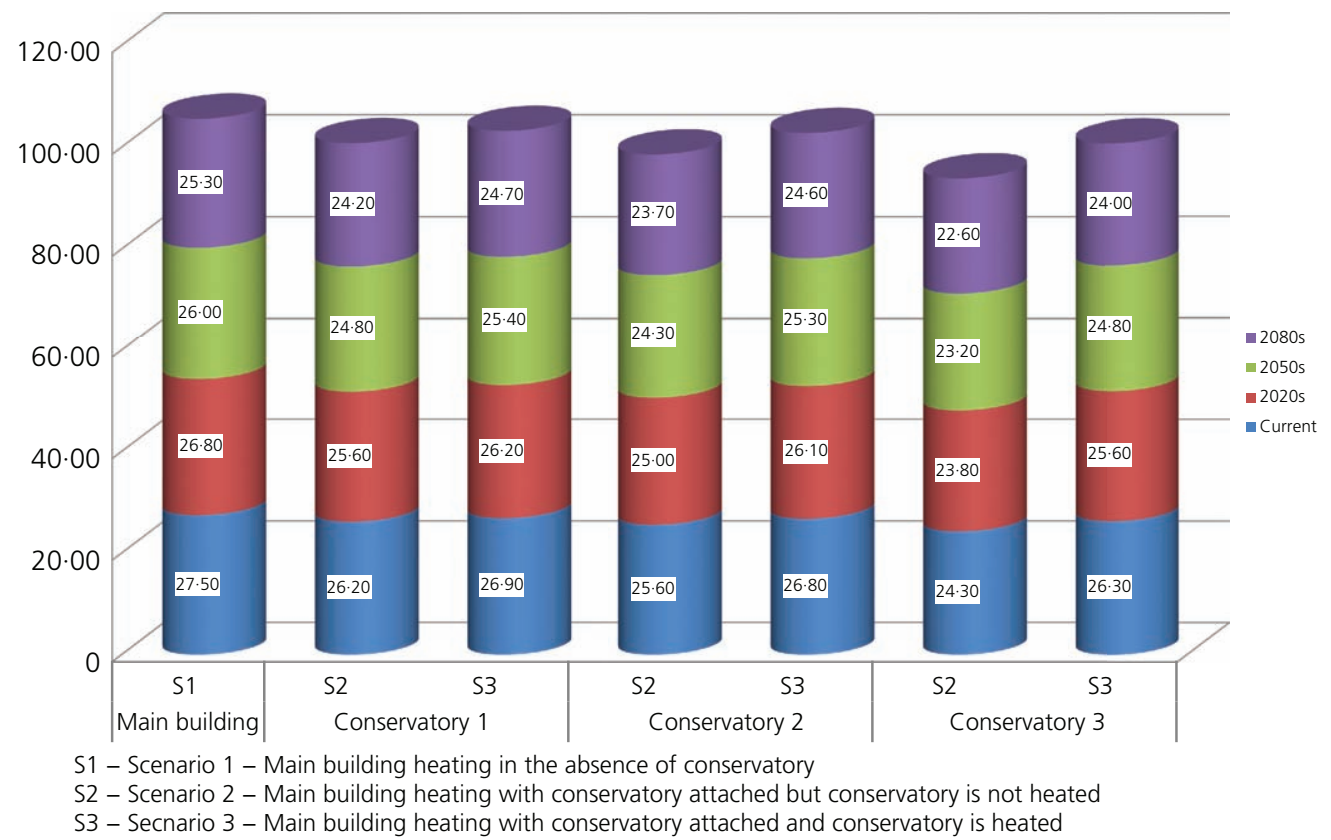

Figure 5. Building emission rate $\left(\mathrm{kgCO}_{2} / \mathrm{m}^{2}\right)$

The annual gas consumption results indicated in Figure 6 show an observable decrease in gas consumption for all of the three conservatory designs in scenario 2 , when the attached conservatory to the main building is unheated throughout the heating season. The declining trend is observed in the respective climate change progression timelines of current, 2020s, 2050s and 2080s for all conservatory designs. The mean percentage decreases of annual natural gas consumption for conservatories 1 to 3 were $7 \cdot 69,9 \cdot 88$ and 14.56 , respectively, and these amount to $5.08,6.57$ and $9.69 \mathrm{kWh} / \mathrm{m}^{2}$, respectively. This declining trend points to a general decrease in annual gas consumption with progressive increase in conservatory floor area/surface area and indicate a significant contribution to dwelling annual natural gas consumption when a conservatory is attached to it. Nevertheless, the reasons for the declining trend could be ascribed to the reasons outlined earlier on in relation to the declining trend associated with the annual energy

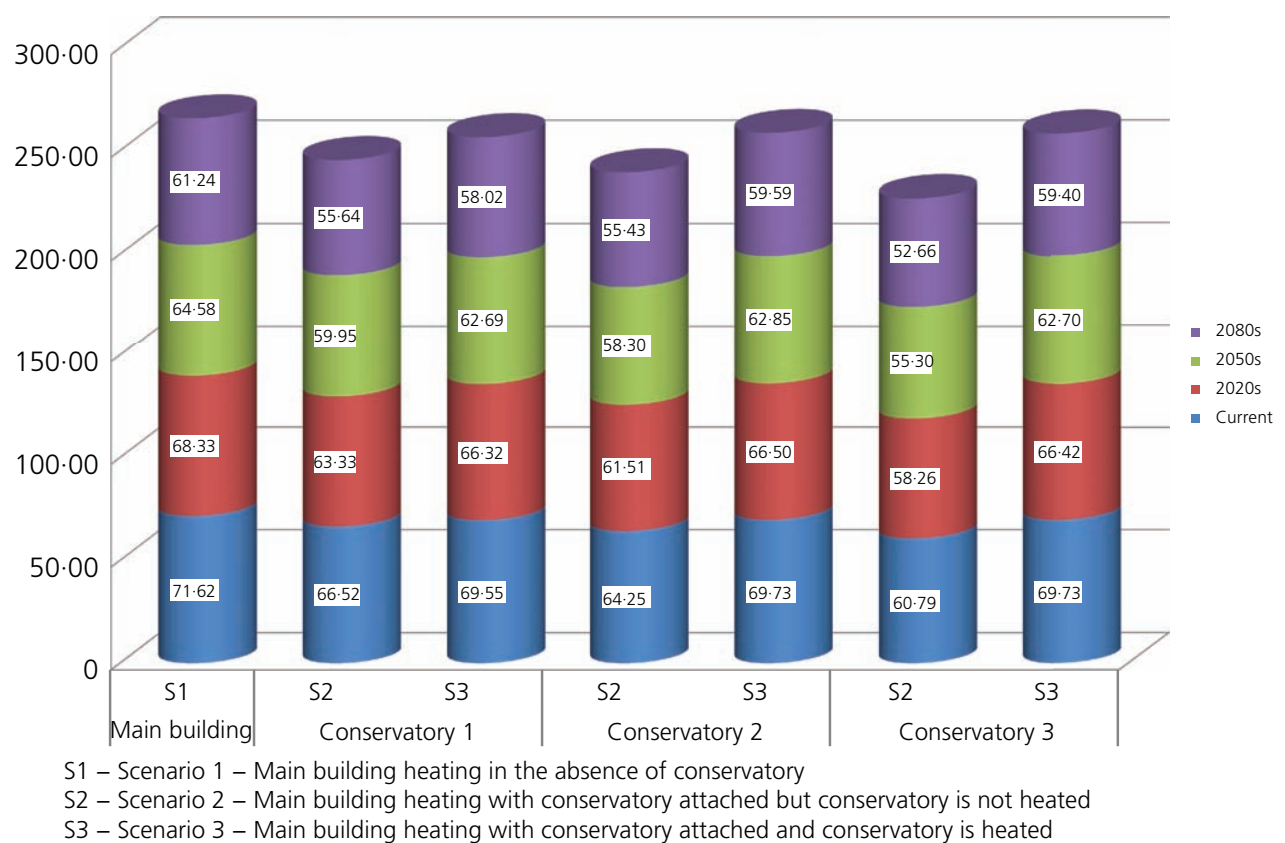

Figure 6. Annual natural gas consumption $\left(\mathrm{kWh} / \mathrm{m}^{2}\right)$ 


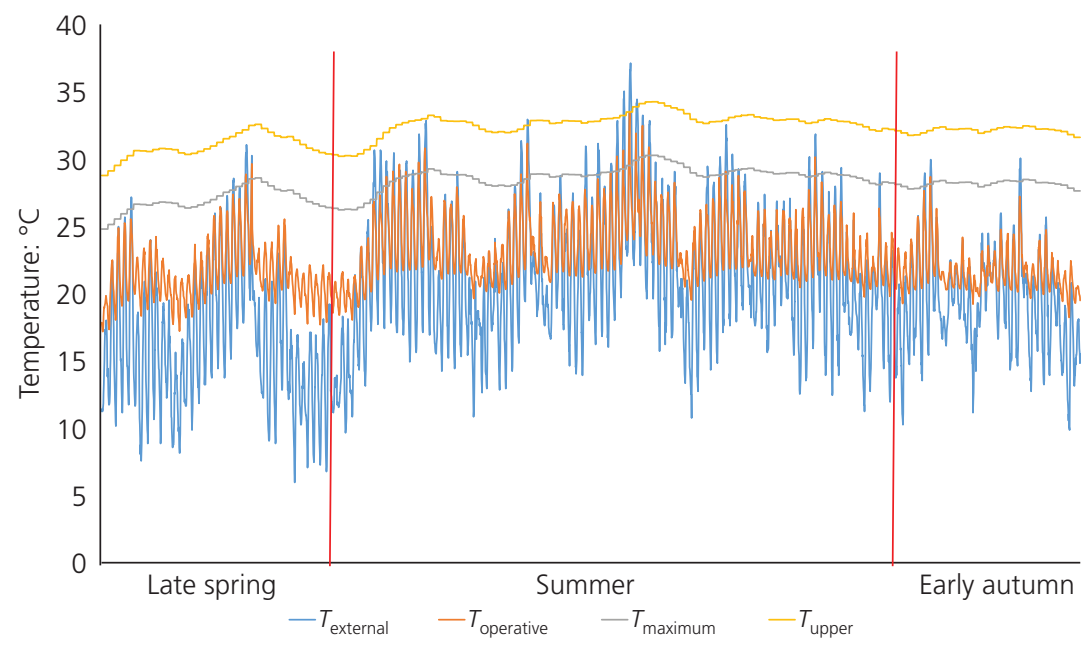

Figure 7. 2050s weather conservatory 3 non-heating season

scenario 1 analysis

consumptions. Again, the gains attributed to the annual natural gas consumption in scenario 2 are also negated in relation to scenario 3 when the conservatories are heated during the heating season. The mean percentages of building emission rate lost due to the heating of the three conservatories were observed to be $4 \cdot 53,7.99$ and 13.73 for the current and future weather data set.

\subsection{Thermal comfort overheating results and analysis}

Figures 7-9 show the Cibse TM52 thermal comfort overheating analysis results for the non-heating season of conservatory 3 designs based on the earmarked simulated ventilation and shading scenarios for the 2050s weather data set. This is an extract of the Cibse TM52 thermal comfort overheating analysis results for the three conservatory designs. The figures stipulate the external

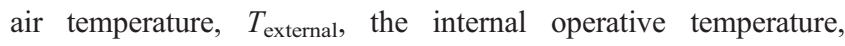

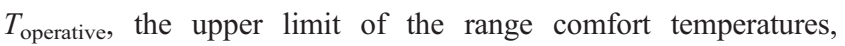
$T_{\text {maximum }}$ and the absolute upper limit for the operative temperature, $T_{\text {upper }}$. The figures indicate the temperature variance for the late spring, summer and early autumn months of May to September as specified in the Cibse TM52 adaptive thermal comfort criteria.

Comparison of Figures 7,8 and 9 indicates that the operative temperature variability generally peaks in summer. In Figure 7, there is evidence of the internal operative temperatures exceeding the threshold comfort temperature at certain times in late spring and early autumn for scenario 1 , where there is no shading. This variability gradually decreases in Figures 8 and 9, reflecting the relevance of night ventilation and shading in scenarios 2 and 3 in mitigating overheating in conservatories.

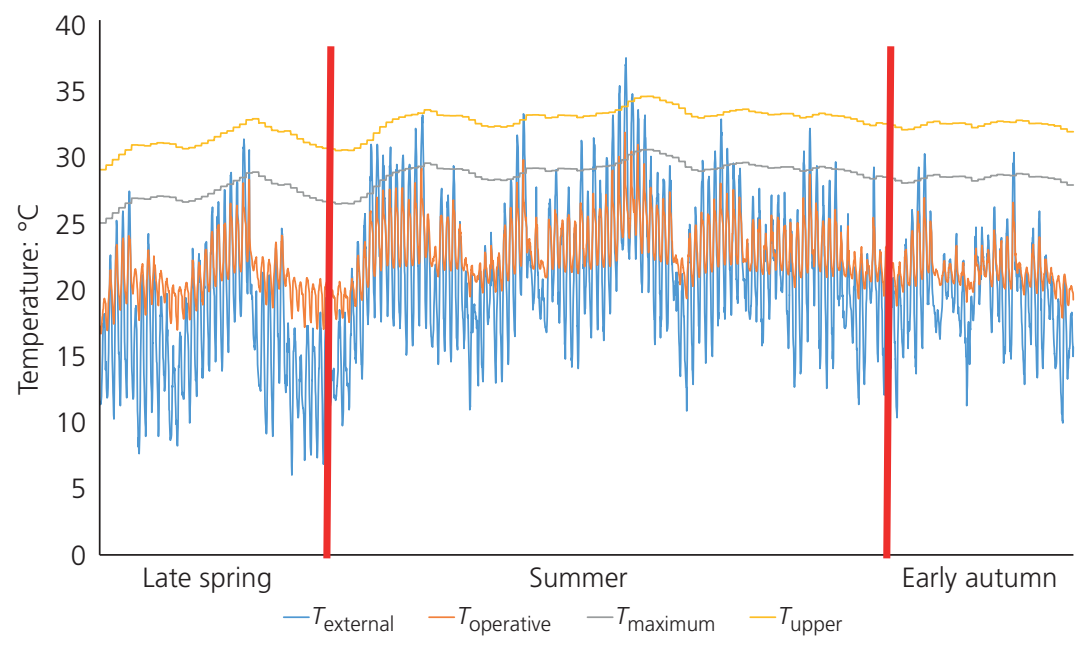

Figure 8. 2050s weather conservatory 3 non-heating season

scenario 2 analysis 


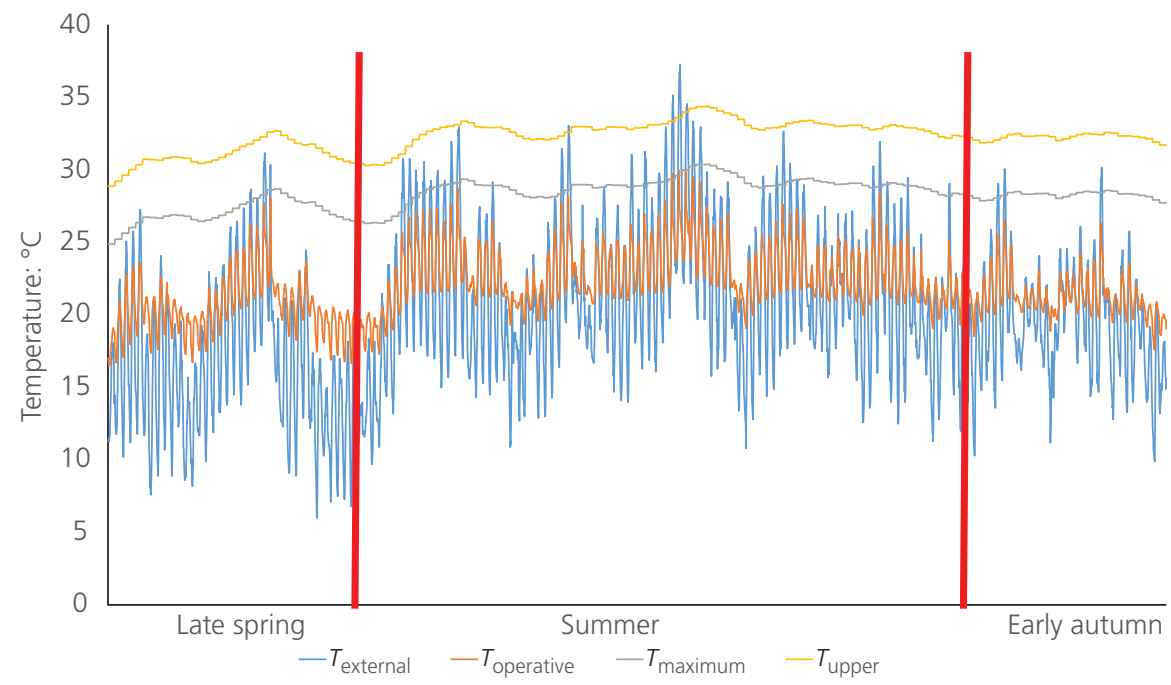

Figure 9. 2050s weather conservatory 3 non-heating season

scenario 3 analysis

Figures 10 and 11 indicate the analysis of the three conservatory designs based on Cibse TM52 overheating criteria of hours of exceedance and daily weighted exceedance. This analysis complements the analysis in Figures 7-9.

In Figure 10, all of the three conservatories fail under scenario 1 for the current and future weather data sets as hours of operative temperature exceeds the 32 limit on hours of exceedance. The limit on hours of exceedance is $3 \%$ of occupied hours. Under scenario 2 , where shading is applied to the roof and south-facing side of the conservatory during day time, coupled with night ventilation, significant reduction of overheating is observed, with all of the conservatories' number of hours with operative temperatures below the limit of hours of exceedance. Scenario 3, where shading is applied to both the east and west section of the conservatories, together with the conditions set out in scenario 2, offers the most effective means of mitigating overheating in conservatories, with no observable overheating during the occupied hours.

Figure 11 shows the peak daily weighted exceedance, which is an indication of the severity of overheating underpinned by the limit of daily weighted exceedance of not more than 6 . The greatest severity of overheating is observed under scenario 1 , with conservatory 3 failing in all future weather patterns. The severity of overheating gradually decreases under scenarios 2 and 3, respectively.

It is only conservatory 3 that once exceeds the absolute upper limit temperature of overheating in the 2050s. Moreover,

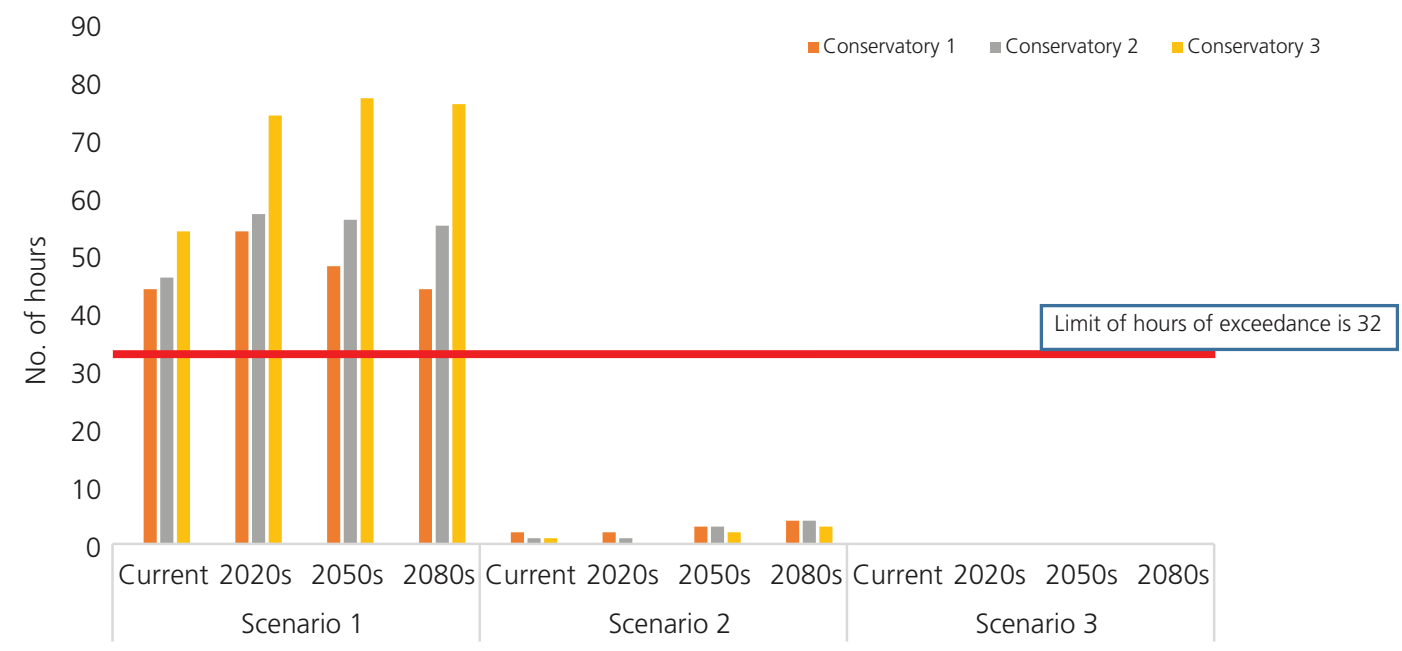

Figure 10. Adaptive thermal comfort criteria - number of hours exceeding comfort range 


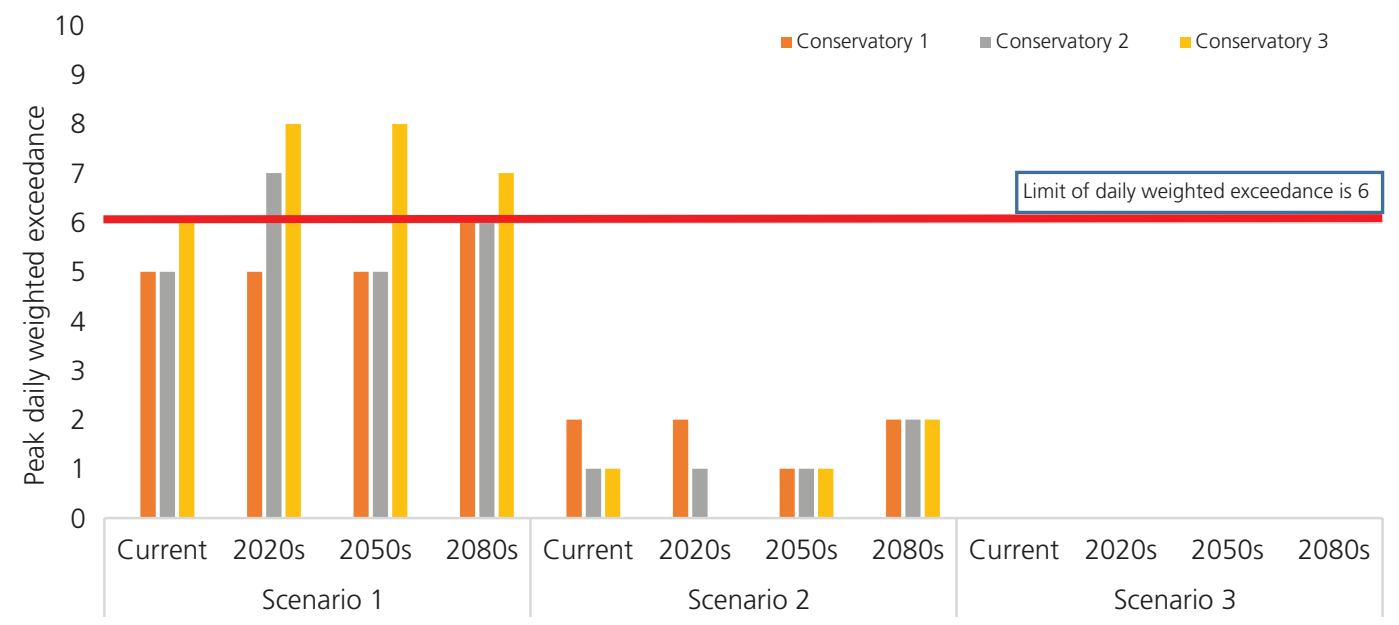

Figure 11. Adaptive thermal comfort criteria - peak daily

weighted exceedance

conservatory 3 is observed to fail two or three comfort criteria under scenario 1 when considering the future weather patterns, but the frequency and severity of overheating are mitigated with the application of the shading and night ventilation scenarios. For the non-shaded conservatory with day ventilation, scenario 1 , the high variability of operative temperatures for the late spring, summer and early autumn suggest that strategic passive provision of shading and ventilation must be in place during this period.

The results thus show that the use of awnings/overhangs to block excessive solar radiation during the non-heating period, coupled with night-time ventilation as specified in scenario 2 , could offer a significant reduction in operating temperatures to enhance thermal comfort. A further reduction in the trend is realised in scenario 3, when additional shading is provided to the east and west facades of the conservatories.

\section{Conclusion}

This study has evaluated the impact of conservatories as a passive solar design on the three key dwelling energy performance indicators of annual energy consumption, building emission rate and annual natural gas consumption for detached dwellings in the UK. An investigation of internal temperatures was also done using Cibse TM52 adaptive thermal comfort methods to assess the overheating of conservatories. The results show the relevance of the Cibse TM52 adaptive thermal comfort criteria in the design of residential conservatories.

Thermal analysis simulation based on synergetic passive design strategies that seek to optimise solar energy gains through varying future climatic conditions based on the Cibse weather data set, variable occupant behaviour, building orientation, adequate provision of thermal mass, advanced glazing, appropriate ventilation and sufficient level of shading, which all influence the potential thermal performance, was conducted on three conservatories of varying sizes.
The simulation results showed that the integration of passive solar strategies in conservatory design could significantly decrease energy consumption, building emission rate and natural gas consumption. The amount of percentage decrease was inversely proportional to the increase of conservatory size when an increment was carried out along the southern orientation of the building facade. This increase in conservatory southern facade dimension facilitated the increase in solar radiation gains during the heating season and also offered a thermal buffer effect. The balanced energy benefits through pre-heating the main building by means of a conservatory do not necessarily replace the mechanical heating systems, but the process offers a noticeable decrease in the thermal performance parameters when the conservatory is not heated during the heating season. Heating conservatories negates the energy and thermal performance gains, with increase in energy consumption, building emission rate and natural gas consumption. Heating conservatories is therefore not in consonance with the energy balance of the use of the conservatory as a passive solar design. The investigations also indicated that the provision of an optimum ventilation strategy, depending on the period of the year, coupled with the efficient design of awnings/overhangs and the provision of external adjustable shading on the east and west facades of the conservatory could significantly enhance the thermal comfort of conservatories. This consideration points to the likelihood of overheating of all nonshaded conservatories with a day ventilation scenario now and in the future, without the application of integrated passive design strategies. This variability suggests that failure to incorporate passive solar strategies in conservatory design would necessitate the introduction of cooling systems in conservatories and thus increase the dwelling energy demand and raise carbon dioxide emissions.

The utilisation of passive solar design has almost no negative impact on the environment, as it does not use any form of operational energy to provide thermal comfort and also does not incur operational cost. Rather a holistic passive solar design which takes cognisance of passive solar principles offers a significant 
Impact of conservatory as a passive solar

design of UK dwellings

Amoako-Attah and B-Jahromi reduction in energy demand and building emission rate. However, passive solar design solutions are underpinned by variable occupant behaviour. Thus, the incorporation of smart house technological solutions such as automatic external shading and demand control ventilation strategies could enhance the design intent of the application of such passive solar principles.

This work has shown the potential of conservatories to serve as an effective passive solar design which can offer a significant and positive contribution to the energy performance and enhancement of thermal comfort of a dwelling, when passive solar design principles are applied and the conservatory is neither heated nor air conditioned. The results show that the judicious integration of passive solar design strategies in conservatories with increasing conservatory size in an elongated south-facing orientation, with an aspect ratio of at least 1.67 , could on average decrease annual energy consumption (by $5 \mathrm{kWh} / \mathrm{m}^{2}$ ), building emission rate (by $2 \cdot 0 \mathrm{kgCO}_{2} / \mathrm{m}^{2}$ ) and annual gas consumption (by $7 \mathrm{kWh} / \mathrm{m}^{2}$ ). Thus this work indicates that passive solar design of conservatories through thermal analysis simulations offers a viable solution to reduce dwelling energy consumption, enhance thermal comfort and help mitigate the impact of climate change, thereby contributing to the achievement of environmental sustainability.

\section{REFERENCES}

Aksoy UT and Inalli M (2006) Impacts of some building passive design parameters on heating demand for a cold region.

Building and Environment 41(12): 1742-1754.

Amoako-Attah J and B-Jahromi A (2013) Impact of future climate change on UK building performance. Advances in Environmental Research 2(3): 203-227, http://dx.doi.org/10. 12989/aer.2013.2.3.203.

Amoako-Attah J and B-Jahromi A (2014) Impact of standard construction specification on thermal comfort in UK dwellings. Advances in Environmental Research 3(3): 253-281, http://dx.doi.org/10.12989/aer.2014.3.3.253.

Amoako-Attah J and B-Jahromi A (2015) Method comparison analysis of dwellings' temperatures in the UK. Proceedings of the Institution of Civil Engineers - Journal of Engineering Sustainability 168(1): 16-26, http://dx.doi.org/10.1680/ensu. 14.00022 .

Anderson B and Michal C (1978) Passive solar design. Annual Review of Energy 3(1): 57-100.

Bakos GC and Tsagas NF (2000) Technology, thermal analysis and economic evaluation of a sunspace located in northern Greece. Energy and Building 31(3): 261-266.

Banos R, Manzano-Agugliaro F, Montoya FG et al. (2011) Optimization methods applied to renewable and sustainable energy: a review. Renewable and Sustainable Energy Reviews 15(4): 1753-1766.

Bataineh KM and Fayez N (2011) Analysis of thermal performance of building attached sunspace. Energy and Buildings 43: 1863-1868.

Boyle G (2012) Renewable Energy Power for a Sustainable Future, 3rd edn. Oxford University Press, Oxford, UK.
BRE (Building Research Establishment) (1988) Exploiting Sunshine in House Design. Eclipse Research Consultants, Building Research Establishment for the Department of Energy's Energy Technology Support Unit, London, UK. BRE (2012) The Government's Standard Assessment Procedure for Energy Rating of Dwellings. SAP 2012 version 9.92 edition. Building Research Establishment, Watford, UK. See https://www.bre.co.uk/filelibrary/SAP/2012/SAP-2012 992.pdf (accessed 13/04/2014).

BRE (2014) Standard Assessment Procedure (SAP 2012), Updated June 2014. Building Research Establishment, Watford, UK. See http://www.bre.co.uk/sap2012/page.jsp?id=2759 (accessed 18/05/2014).

BSI (1991) BS 5925:1991: Code of practice for ventilation principles and designing for natural ventilation. BSI, London, UK.

BSI (2007) BS EN 15251: 2007 Indoor environmental input parameters for design and assessment of energy performance of buildings addressing indoor air quality, thermal environment, lightning and acoustics. BSI, London, UK.

Burns L and Kabak M (2014) Lighting by Passive and Active Solar Use Design. Burnham-Moores Center, University of San Diego, MSRE, San Diego, CA, USA. See http://www.josre.org/wp-content/uploads/2012/10/ Lighting-Systems-by-Lauren-Burns-and-Matt-Kabak.pdf (accessed 18/07/2014).

Cibse (Chartered Institution of Building Services Engineers) (2006) CIBSE Guide A - Environmental Design. Cibse, London, UK.

Cibse (2009) The Use of Climate Change Scenarios for Building Simulation: The Cibse Future Weather Years. Cibse, London, UK, Cibse TM48.

Cibse (2013) The Limits of Thermal Comfort: Avoiding Overheating in European Buildings. Cibse, London, UK, Cibse TM52.

Cibse (2014) Design for Future Climate Case Studies. Cibse, London, UK, Cibse TM55:2014.

Clarke JA, Johnstone CM, Kelly NJ, Strachan PA and Tuohy P (2008) The role of built environment energy efficiency in a sustainable UK energy economy. Energy Policy 36(12): 4605-4609.

CLG (2010a) Approved Document L1B: Conservation of Fuel and Power in Existing Dwellings. The Building Regulations 2010. National Building Specification, Newcastle upon Tyne, UK. See http://www.planningportal.gov.uk/uploads/br/ BR_PDF_ADL1B_2010.pdf (accessed 20/07/2014).

CLG (2010b) Approved Document F1: Means of Ventilation. The Building Regulations 2000. National Building Specification, Newcastle upon Tyne, UK. See http://www. planningportal.gov.uk/uploads/br/BR_PDF_ADF_2010.pdf (accessed 22/07/2014).

EDSL (Environmental Design Solutions Ltd.) (2014) Natural Ventilation and Passive Design. Milton Keynes, UK. See http:www.edsl.et/main/Software/Designer/NVandPD.aspx (accessed 10/05/2014).

English H and Walker A (2000) Passive Solar Design: The Foundation for Low-energy Federal Buildings. 
Engineering Sustainability

Volume 169 Issue ES5
Impact of conservatory as a passive solar

design of UK dwellings

Amoako-Attah and B-Jahromi
US Department of Energy, Washington DC, USA.

See http://www1.eere.energy.gov/femp/pdf/26015.pdf (accessed 08/07/2014).

EREC (2000) Passive Solar Design for the Home. See http://www. nrel.gov/docs/fy01sti/29236.pdf (accessed 14/07/2014).

FENSA (2014) The Fenestration Self-Assessment Scheme. See http://www.fensa.co.uk (accessed 15/07/2015).

Hulme M, Jenkins GJ, Lu X et al. (2002) Climate Change Scenarios for the United Kingdom: The UKCIP02 Scientific Report. Tyndall Centre for Climate Change Research, School of Environmental Sciences, University of East Anglia, Norwick, UK.

Jenkins GJ, Murphy JM, Sexton DMH et al. (2009) UK Climate Projections: Briefing Report. Met Office, Hadley Centre, Exeter, UK.

Kochaniuk P (2012) Passive Solar Design. See http://www. greenextension.eu/pdf/Passive\%20solar\%20design.doc (accessed 14/07/2014).

Kruzner K, Cox K, Machmer B and Klotz L (2013) Trends in observable passive solar design strategies for existing homes in the U.S. Energy Policy 55: 82-94.

Lau CCS, Lam JC and Yang L (2007) Climate classification and passive solar design implications in China. Energy Conversion and Management 48(7): 2006-2015.

Mihalakakou G and Ferrante A (2000) Energy conservation and potential of a sunspace: sensitivity analysis. Energy Conversion and Management 41(12): 1247-1264.

Monahan J and Powell JC (2011) A comparison of the energy and carbon implications of new systems of energy provision in new build house in the UK. Energy Policy 39(1): 290-298.

Morrissey J, Moore T and Horne RE (2011) Affordable passive solar design in a temperate climate: an experiment in residential building orientation. Renewable Energy 36(2): 568-577.

Mottard JM and Fissore A (2007) Thermal simulation of an attached sunspace and its experimental validation. Solar Energy 81(3): 305-315.

Murphy JM, Sexton DMH, Jenkins GJ et al. (2009) UK Climate Projections Science Report: Climate Change Projections. Met Office Hadley Centre, Exeter, UK.

Mylona A (2012) The use of UKCP09 to produce weather files for building simulation. Building Services Engineering Research and Technology 33(1): 51-62.

Oliveira Panao MJN, Camelo SML and Gonalves HJP (2012) Solar load ratio and ISO 13790 methodologies: indirect gains from sunspace. Energy and Building 51: 212-222.

Passerini F, Albatici R and Frattari A (2013) Quasi-steady state calculation method for energy contribution of sunspaces: a proposal for the European standard improvement. Proceedings of Building Simulation Applications BSA 2013, 1st IBPSA Italy Conference, Bozen-Bolzano, Italy, pp. 141-150.

Passivhaus Homes (2013) History of Passivhaus.

See http://www.passivhaushomes.co.uk/passivhaushistory.html (accessed 14/06/2013).

Planning Portal (2014) Guide to the Planning Permission and Permitted Development Regimes for Conservatories. See http// www.planningportal.gov.uk/permission/commonprojects/ conservatories/miniguide (accessed 14/07/2014).

Pulselli RM, Simoncini E and Marchettini N (2009) Energy and energy based cost benefit evaluate of building envelopes relative to geographical location and climate. Building and Environment 44(5): 920-928.

Ralegaonkar RV and Gupta R (2010) Review of intelligent building construction: a passive solar architecture approach. Renewable and Sustainable Energy Reviews 14(8): 2238-2242.

Spanos I, Simons M and Holmes KL (2005) Cost savings by application of passive solar heating. Structural Survey 23(2): 111-130.

Taleb HM (2014) Using passive cooling strategies to improve thermal performance and reduce energy consumption of residential buildings in UAE buildings. Frontiers of Architectural Research 3(2): 153-165.

Tian W and de Wilde P (2011) Uncertainty and sensitivity analysis of building performance using probabilistic climate projections: a UK case study. Automation in Construction 20(8): 1096-1109.

UK Climate Projections (2010) UK Climate Projections 2009 Weather Generator User Interface (Version 1). See http:// ukclimateprojections-ui.defra.gov.uk/ui/admin/login.php (accessed 19/04/2013).

van Esch MME, Looman RHJ and de Bruin-Hordijk GJ (2012) The effect of urban and building design parameters on solar access to the urban canyon and the potential for direct passive solar heating strategies. Energy and Buildings 47: 189-200.

Williams D, Elghali L, France C and Wheeler RC (2011) Projecting building energy demand using probabilistic weather conditions accounting for climate change. CIBSE Technical Symposium. DeMontfort University, Leicester, UK.

Yohanis YG and Norton B (2002) Useful solar heat gains in multizone non-domestic buildings as a function of orientation and thermal time constant. Renewable Energy 27(1): 87-95.

Zain-Ahmed A, Sopian K, Othman MYH, Sayigh AAM and Surendran PN (2002) Daylighting as a passive solar design strategy in tropical buildings: a case study of Malaysia. Energy Conversion and Management 43(13): 1725-1736.

\section{HOW CAN YOU CONTRIBUTE?}

To discuss this paper, please email up to 500 words to the editor at journals@ice.org.uk. Your contribution will be forwarded to the author(s) for a reply and, if considered appropriate by the editorial board, it will be published as discussion in a future issue of the journal.

Proceedings journals rely entirely on contributions from the civil engineering profession (and allied disciplines). Information about how to submit your paper online is available at www.icevirtuallibrary.com/page/authors, where you will also find detailed author guidelines. 